\title{
Co-Evolutionary Prospects in Tourism
}

\author{
Marco Valeri ${ }^{1} \&$ Leslie Fadlon ${ }^{2}$ \\ ${ }^{1}$ Research Fellow of Organizational Behavior, Faculty of Economics - Niccolò Cusano University in Rome, \\ Italy \\ ${ }^{2}$ Phd student in Governance and Management for Business Innovation, Faculty of Economics, Niccolò Cusano \\ in Rome, Italy \\ Correspondence: Marco Valeri, Research Fellow of Organizational Behavior, Faculty of Economics - Niccolò \\ Cusano University, Don Gnocchi Street, 00166 Rome, Italy. E-mail: marco.valeri@unicusano.it
}

Received: March 8, 2018

doi:10.5539/ijbm.v13n9p95
Accepted: June 24, 2018

Online Published: August 1, 2018

URL: https://doi.org/10.5539/ijbm.v13n9p95

\begin{abstract}
The purpose of this paper is to verify whether the nature of the relationship between a tourist destination and tourist enterprises operating within its territory, can be defined as co-evolutionary. This paper derives from the continuation of previous researches of ours about the topic of destination management and destination governance. The theoretical background of this paper is based on the following research question: within the framework of the international tourist scenario, are there tourist hospitality models designed as a prototype of co-evolution between the tourist destination and its territory? In this paper, the analysis perspective which is considered the most appropriate to qualify the nature of the relationship among a given tourist destination and its tourist enterprises is the co-evolutionary perspective. According to such perspective, tourist enterprises co-evolve together with tourist destinations, while looking for long-term competitive advantages: tourist enterprises are considered critical resources to the development of the territory and vice versa. The co-evolutionary process implies the identification of a governance body able to exploit and enhance the systemic resources made available by the territory and to inspire the management approach of the different tourist enterprises. The absence of specific case studies represents a limit of the present paper. Hence, with a view to a subsequent future research, we will continue the proposed analysis by enriching it with empirical evidence, which will be useful to foster the debate on the subject matter and for the related entrepreneurial and management implications.
\end{abstract}

Keywords: entrepreneurship, destination governance and destination management, co-evolution, sustainable development, network, competitive advantage

\section{Introduction}

In an increasingly complex tourist scenario, the competitiveness of a tourist destination depends on the entrepreneurial ability of each tourist enterprise operating in that area to measure against competitor tourist destinations, at both national and international level. Therefore, each tourist destination needs to define its operative borders and identify a governance body, whether public, private or a mixture of both (Pencarelli, 2001), able to develop a strategic direction that will enhance the enterprises and the potential highlights of the area. (Pechlaner \& Weiermair, 2000; Franch, 2002; Golinelli, 2002; Sainaghi, 2006; Martini, 2008; Valeri \& Baiocco, 2012). In this sense, the systematic ability of tourist enterprises to perceive and evaluate the external context is crucial, as it requires responses that need to be more and more accountable. (Golinelli \& Simoni, 2005). This could generate a possible source of creativity for a more sustainable development (Pechlaner et al., 2009; Valeri et al., 2016). The governance and the management of tourist enterprises have the responsibility to promote the growth of a favorable organizational environment supporting the development of new tourist products/services that need to be economically profitable, socially accepted by the hosting community and aimed at protecting local environmental resources. This can be achieved by creating a working environment with human resources having strong innovative potentialities, focused on exploring new paths of development and willing to take significant risks at reasonable costs. (Schianetz et al., 2007). The above also requires a stimulating environmental framework able to promote the development of challenging shared targets, which can only be achieved in a working context that supports the growth of new knowledge. The ability to innovate and compete successfully depends not only on the potential of the individual enterprises but also on their ability to manage the network of relationships tying the enterprises together. As the management literature has been affirming for years, the ability 
to oversee the dynamics of the network of internal and external relationships allows enterprises to compete successfully in a hypercompetitive framework. Therefore, the research questions upon which the theoretical background of the paper is based shall be: within the framework of the international tourist scenario, are there tourist hospitality models designed as a prototype of co-evolution between the tourist destination and its territory? The article is framed into three main parts. The first part of the paper offers an effort of systematization of national and international literature on the concept of tourist destination and its governance issues. The second part is dedicated to the analysis of the co-evolutionary relationship between the tourist destination and the tourist enterprise. The third and last part focuses on the aspects of networking among the different actors who, within the tourist destination and at different levels, co-operate to the planning and the realization of the tourist offer system.

\section{Ranking of Italy as a Tourist Destination in the International Tourist Scenario}

The tourist industry has always played a strategic role in the world economy. Its economic significance, as well as cultural, social and educational, has been increasing at very fast rates since the second half of the Twentieth Century. In 2016, international tourists confirmed Italy in fifth place among the most visited tourist destinations worldwide. According to the United Nations World Tourism Organization (UNWTO), the international arrivals, throughout the year, amounted to 1.24 billion units, which is in excess of around 3.9\% compared to the previous year. During the same period, the level of spending of international travelers in Italy amounted to 36.4 billion Euros, that is $+23 \%$ compared to 2015 . In the classification of year 2016 regarding the most visited European destinations by international tourists, Italy ranks top three as for presences of tourists in accommodation services, soon after Spain and France, with a share of $14 \%$ out of the total of European Union nations (stable compared to 2015). Italy, Spain, France and Germany together cover more than half (57.4) of the entire touristic presences in the Continent. In 2016, the tourist industry accounted for $10.3 \%$ of Italian GDP, employing around 2.7 million people, equal to $10.9 \%$ of the Italian national employment (Corporate Annual Report ENIT, 2017).

Italy, as a tourist destination, can count on a significant confluence of artistic, historical and landscape values that make this country stand out in the world.

This abundance of resources has a corresponding relevant organization solidity as far as the accommodation offer is concerned and an undiscussed vital hospitality management.

This has allowed Italy as a tourist destination to survive in the long term, maintaining, over the last three decades, the fourth position for number of foreign tourists compared to other international tourist destinations worldwide. Within the European tourist scenario, countries as Denmark, Portugal, Holland, Luxemburg and the United Kingdom have experienced high growth rates in tourism. In a global tourist perspective, over 1.2 billion of international arrivals have been registered. France, although confirmed in the first place, has undergone a decrease of $4 \%$ following the terroristic attacks, Egypt has suffered a $40 \%$ decrease and Turkey has lost around $30 \%$ of tourist flows. It seems as though Cyprus, Spain, Malta and Croatia have been benefiting from this situation, with a double-digit growth rate. Considering possible political factors, initial estimates show how Donald Trump's sovereignty approach may have caused a $2.3 \%$ drop of arrivals in the United States. According to the report presented by Unicredit, one of the main Italian banks, in partnership with Touring Club Italiano (2016), Europe remains the most visited tourist destination by international travelers, with 620 millions of arrivals, followed by Asia and the Pacific and then the United States (201 million of arrivals). In 2016 the highest growth rates were those of Asian-Pacific areas, Africa and America ( $+4.8 \%)$, while Middle East has suffered a decrease $(-4.1 \%)$ and Europe had only a limited increase $(+2 \%)$. Countries that generated the highest spending rate for outgoing tourism were China, ranking 1st place, followed by the USA and Germany. Russia only made it to the 6th place, as a result of a $31 \%$ drop compared to 2014 . Within the Italian trend, Germany is the first reference market (53.3 million of presences), while China enters the Top 10 for the first time, with 5.4 million of presences. Incomes in Italy for year 2016 have also been on a positive trend: 36.4 billion of Euros coming from international tourism, increased 2.3\% compared to 2015 (Bank of Italy Euro system - Survey on international tourism, 2017).

\section{Analysis Approaches of a Tourist Destination}

Over the years, the concept of tourist destination has been the subject matter of a heated scientific debate that has involved numerous national and international studies (Pechlaner et. al., 2012; Borzyszkowski, 2013). Nevertheless, until now there is still no univocal and satisfying definition of the concept of tourist destination, both from the interpretative and the managerial perspective. This justifies the existing confusion and the degree of difficulty to reach a fully convincing theoretical framework. While recognizing the difficulties involved in offering an effort of systematization of the existing literature, the doctrinal debate on the concept of tourist 
destination can be led back to two different analysis approaches (Valeri, 2013):

a) touristic demand, which emphasizes the destination as a tourist product or rather as a set of natural or artificial appealing factors able to attract tourists (Bieger, 2000; Casarin, 2007);

b) touristic supply, which emphasizes the importance of the offer system and of the tourist enterprises operating in the tourist destination (Tamma, 2000; Brunetti, 1999; Martini, 2002). According to such approach, the tourist destination is seen as an organized entity focused on the strategic role of the tourist offer system and of the tourist enterprises that, operating in the same destination, contribute to its development.

These two-analysis perspectives - touristic demand and tourist supply - have produced a wide range of positions supported by eminent academics, which have finally led to the theorization of an integrated approach.

The assumptions of both analysis perspectives merge into this integrated approach (Leiper, 1979; Della Corte, 2009; Buhalis, 2000; Franch, 2002). The integrated approach pinpoints the need, for the destination and the tourist enterprises operating in it, to adopt a considerably more managerial orientation than in the past.

\section{Governance and Management of Tourist Destination}

The governance of a tourist destination can be considered as a system of decisions and actions aimed at consolidating and increasing the competitiveness of the tourist destination over time, defining clear and shared development goals among all the actors of the tourist system (Ruhanen et al, 2010; Baggio \& Cooper, 2010; Pechlaner et al., 2011; Ford, 2012; Paniccia et. al, 2014). Therefore, the governance body, whether public, private or a mixture of both, has highly complex and structured functions and is able to determine the strategic orientation of the destination exercising financial and strategic territorial control. In particular, the governance body has the task to understand and promote the tangible and intangible elements that characterize the cultural identity of a destination compared to its competitors, at local, national and international level (Valeri, 2016).

This implies a broad shared decision-making process, either for direct or indirect arrangements, at governance level of both each single tourist enterprise and of tourist destinations. Moreover, all decisions shall be aimed at increasing the attractiveness of the territory, and consequently, the competitiveness of the tourist destination. (Sciarelli, 2007).

The governance activity includes actors/individuals who have an interest in the tourist destination (e.g. single managers, groups of workers) and/or an interest for the tourist destination: in this regard, reference is made to organizations considered "relevant" in the framework where the tourist destination operates (the so-called stakeholders).

Some of these stakeholders directly influence the objectives of the tourist destination (e.g. suppliers or tourist service brokerage firms); others represent either a public or a social interest towards the tourist destination, e.g. State organizations or citizens associations (Pechlaner et al., 2011; Beritelli \& Bieger, 2014; Pechlaner et al., 2014).According to prestigious researchers, where the model of the tourist fragmentation prevails, it is extremely "difficult to devise activities of destination governance expressing a strong and shared tourist offer management". On the other hand, in contexts characterized by cooperation models, with lesser fragmentation, it is easier to identify key subjects able to play significant roles within the destination (Tamma, 2002). Within this framework the governance body is in charge of the definition of the territory development strategy (Golinelli C.M., 2002). Its activity aims at the creation of value for the territorial system through an on-going interpretation and redefinition of the territorial vocation.

The main governance activities can be summarized as follows:

1.defining specific goals, development guidelines and priority actions of the system;

2.provisioning and allocating resources;

3. coordinating territory elements and development activities;

4.identifying new business opportunities;

5.implementing projects for the development and the promotion of the territory.

Identifying a governance body is a necessary but not a sufficient condition to develop an integrated tourist offer within a tourist destination. Influential researchers believe that it is necessary to support the governance body with a meta-management entity, having the specific task to address tourist destination enterprises towards strategic coherent paths (Pencarelli, 2001). The meta-management body shall only support, and not substitute, the governance body, with the clear objective to facilitate shared processes of coherent strategic decisions among 
all actors, both private and public, who interact within the tourist destination.

Other researchers believe that the meta-management body should have the role of facilitating, carrying out the following activities (Martini, 2002):

1. engaging local actors in the definition of the strategic approach, highlighting benefits and overcoming conflicts;

2. officializing the relationship between the governance body and the single enterprises;

3. defining the control mechanisms and penalty measures against opportunistic attitudes;

4. defining the transparency procedures for the distribution of results achieved.

Managing a tourist destination is an arduous job, as well as managing a tourist enterprise. Difficulties lie in the planning of the strategic decisional processes and in the subdivision of the power of control over resources within the tourist destination. This can be observed in both strongly hierarchical tourist destinations, with a well-identified strategic and managerial hub, and in corporate and community tourist destinations (Bieger, 1998; Flagestad \& Hope, 2001). They both differ in terms of planning of tourist offer and therefore they experience different governance issues.

On one hand, identifying a governance body within a tourist destination is considered essential, whether this is public, private or an outcome of a balanced and diversified cooperation between private and public actors (Migliaccio et al., 2004). On the other hand, there is a real sense of how hard is to develop cooperative relationships among these actors in order to implement actions aiming at increasing the quality of tourist services compared to competing destinations (Breukel \& Go, 2009; Baggio \& Cooper, 2010; Volgger \& Pechlaner, 2014).

\section{The Co-Evolutionary Relationship between Tourist Destinations and Tourist Enterprises}

The most suitable analysis perspective to better qualify the nature of the relationship between tourist destinations and tourist enterprises is the co-evolutionary perspective.

According to this approach, tourist enterprises co-evolve with tourist destinations in the research of long-term competitive advantages: tourist enterprises are considered crucial for the development of the territory and vice-versa (Paniccia, 2006; Paniccia \& Leoni, 2017). The mutual dependence between the enterprise and the environmental framework significantly affects the ability to innovate, and consequently, the competitiveness of the individual enterprises as well as that of entire territories. This presumes strong abilities to explore and evaluate new business opportunities that the dialogue with the environmental framework is able to offer. The outcome is a planning and distribution of tourist services coherent with the real needs of the reference framework as well as with the enterprise's technical-organizational potential and its human resources. Therefore, enterprises and local contexts have to co-evolve in search of competitive advantages, the first being essential for the development of the second and vice-versa. In order to co-evolve, a tourist enterprise has to stimulate the reference environmental framework, influencing the strategic actions of actors that operate in it, in a sustainable perspective. (Valeri, 2015; Valeri et al., 2016). This entails the ability of an enterprise to establish long-lasting relationships with the environmental framework, by engaging all actors of the territorial system through shared goals, motivations, knowledge and deadlines in order to create value in the co-evolution process (Cafferata, 2014). Within the Italian tourist scenario, the albergo diffuso can be considered as the Made in Italy response to the co-evolutionary process triggered between the tourist destination and the territory, identifying a new role for the small accommodating business in the local economic and social system (Valeri \& Paoloni, 2017). It is about small businesses managed by self-employed, handymen, entrepreneurs, who need to be encouraged because, although in many different ways, they succeeded to integrate with the territory. In their visionary approach, they managed to blend traditional elements of the accommodation offer with relevant social and economic factors, such as the authenticity of territories and buildings, food and wine traditions, folklore and artisanship (Paniccia et al., 2014; Paniccia \& Leoni, 2017). The enterprise-environment relationship results in a dynamic network of relations, voluntary and structured, that bond the enterprise with other organizations operating in the same environmental framework.

Co-evolving is not easy (Weick, 1969; Lewin \& Volberda, 1999; Lewin et al., 1999; Paniccia, 2006; Volberda \& Lewin, 2003). The co-evolutionary process implies the identification of a governance body able to enhance the systemic elements that the territory offers and to stimulate the organizational behaviors of the different tourist enterprises. This happens through a conscious strategic orientation, shared by all actors - whether they belong to the business or not, whether directly or indirectly involved in the evolutionary dynamics of the territory - that enables to improve the consonance and resonance circumstances with the other tourist enterprises (Trunfio, 2008; 
Golinelli, 2010). The governance and the management of tourist organizations have the responsibility to promote the development of a favorable organizational environment that supports the development of new tourist products/services that are economically profitable, socially accepted by the hosting community and aimed at protecting local environmental resources. How? By creating a working environment with human resources having strong innovative potentialities, focused on exploring new paths of development and willing to take significant risks at reasonable costs. (Schianetz et al., 2007). This requires the existence of a stimulating environmental framework able to promote the development and the participation in challenging shared targets, which can be achieved in a working context that supports the growth of new knowledge. Hence, if the competitiveness of tourist organizations is measured by the ability to provide tourists with the chance to live unique experiences, their governance and management will have the delicate task to develop a series of actions able to:

a. promote and enhance the local intangible cultural heritage of the hosting community;

b. engage small businesses, whether local or not, that might become sources of financing;

c. enhance the quality of the tourist offer based on intangible resources and on integrated social and environmental aspects;

d. improve the quality of accommodation and tourist services.

Creating and maintaining such a context implies the existence of an internal organization structure specifically dedicated and oriented towards the development of innovation, where human resources are constantly challenged. Another element to take into consideration to create a suitable organization context is the setting up of an efficient and effective control system. The difficulty faced by the enterprises that want to create tourist product/services is trying to match the freedom of ideas with the efficiency of the development process. Control activities must not be too strict, not to prevent the most authentic initiatives. Creating the right degree of engagement, the development of new ideas would be easier (Landorf, 2009; Epstein et al., 2010). However, all the above is not enough, if tourist organizations do not implement an efficient and effective incentive system able to inspire creativity and autonomy, rewarding the actors involved in the development of new products/services and granting suitable recognitions, whether monetary or not (e.g. promotions), according to job profiles. All essential ingredients to achieve an organizational balance. This entails the activation of mutual relationships by both tourist destinations and tourist enterprises.

\subsection{An Analysis Model of Co-Evolution}

Co-evolving is not easy (Weick, 1969; Lewin \& Volberda, 1999; Lewin et al., 1999; Paniiccia, 2006; Volberda \& Lewin, 2003) and defining a thorough management model that can represent the process of co-evolution is just as difficult. Below is a matrix of co-evolution between a tourist destination and a tourist enterprise (Fig.1), that is the result of the re-elaboration of management models confimed by national and international literature (Hrebiniak \& Joice, 1985; Golinelli C. M. 2002; Cafferata, 2014).

The matrix can be interpreted in either a static or a dynamic way. It considers four different configurations of tourist offer system, determined according to the intensity of the aptitude shown by a tourist destination and a tourist enterprise in being able to activate mutual relationships with actors operating in the territory (Ma \& Hassink, 2013). The position in one of the four quadrants represents the different degree of aptitude (Fig. 1).

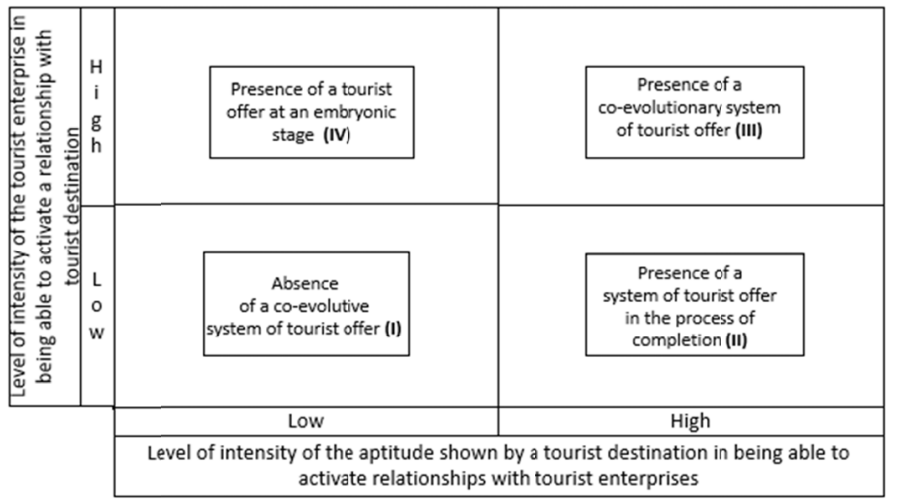

Figure 1. Matrix of co-evolution between a tourist destination and a tourist enterprise 
The four configurations are the following:

1. absence of a co-evolutionary system of tourist offer (I). This group is characterized by the absence of a governance body of the tourist destination able to understand and exploit the elements featuring the territory identity, compared to competing destinations and to other tourist enterprises operating in it. This situations may jeopardize the competitiveness of the tourist destination and above all the outliving of the single tourist enterprises;

2. presence of a system of tourist offer in the process of completion (II). This is the most recurring configuration. It is characterized by the presence of a governance body of the tourist destination involved in the exploitation and promotion of local resources. Nevertheless, cooperation processes between tourist enterprises and local actors are not yet well structured and therefore still on the way to be completed;

3. presence of a co-evolutionary system of tourist offer (III). This group is characterized by the presence of a governance body of the tourist destination with full powers of orientation and coordination, focused on enhancing the territory identity conceived as a source of vitality of the tourist destination. The presence of a co-evolutionary system of tourist offer fully meets the necessary requirements allowing to put in place concrete actions that aim at exploiting the territory and that are vital to increase its competitiveness;

4. presence of a tourist offer at an embryonic stage (IV). It is characterized, on the one hand, by the absence of a tourist destination's governance body in charge of coordinating and addressing the activity of exploitation of the territory and, on the other hand, by the prevalence of self-managed processes put in place by tourist enterprises. The extended absence of a governance body able to aggregate decisions and strategic actions on the territory may cause recession.

The position within one of the four quadrants of the co-evolutionary matrix depends on the synergic and mutual relationship between the ability of tourist enterprises to create value within the tourist destination they belong to and the level of attractiveness of the resources of the tourist destination itself. This prerequisite represents a significant and crucial leverage for the strategic orientation of the governance body of a tourist destination, with the aim to improve the competitiveness of the environment framework and to guarantee the outliving of local enterprises, whether tourist or not.

\section{The Strategic Role of Tourist Network}

In today's complex competitive context, businesses need to own an increasingly qualified background of resources and expertise in order to compete with an ever more challenging competition. This results in an increase of specialization of the single enterprise that has actually created a reduction in the number and in the variety of shared knowledge and capabilities (Valeri \& Paoloni, 2016). The deep cognitive distance between individual enterprises and, at the same time, the lack of necessary resources to gain new knowledge may represent elements of friction for the cooperation processes. In this sense, networking can represent an organizational model suitable to promote the growth of small and medium-sized enterprises, which have only limited knowledge and resources essential to compete in an ever more complex market. Within the international scientific debate, researchers have focused their studies on the analysis of the evolutionary dynamic of networks and on the factors that influence their success over time (Gulati \& Gargiulo, 1999; Soda et al., 2004; Das \& Teng, 2002; Yin et al., 2012). Thanks to an interdisciplinary approach, that over the years has enriched the debate on the theory of networks (Parkhe et al., 2006), it is possible to mention some inputs identifying the evolutionary phases of the creation and development of inter-organizational relationships such as:

1) The reasons that have determined the origin of the network. These highlight, on one hand, both the central role played by elements related to the reputation of individuals and of the organization, and the existence of previous relationships. On the other hand, they also highlight the central role of those elements linked to possible investments, to the perceptions about the uncertainty of the business and the relevant actions to implement;

2) The necessary circumstances to build any kind of relationship between enterprises, starting from the features of potential members and their will to meet and agree on future conduct regulations;

3) The aptitude towards an agreement on future conduct rules and on control mechanisms aimed at governing conflicts.

In the specific case of tourist destinations and enterprises, the benefits deriving from belonging to a network can be: 
1. economic benefits: differentiation/diversification of the tourist offer in line with the specific needs of the customer segments, development through expansion/integration in new emerging markets, design of tourist products through the exploitation and enhancement of local resources;

2. benefits from design and development of tourist products/services: greater access to sensitive information, by activating intelligence systems where possible, increased efficiency and effectiveness in productive processes, and optimization of costs.

Belonging to a network can promote the development of innovation of tourist enterprises involved and stimulate the creation of new business realities that operate in alternative markets, exploiting new knowledge and meeting new clients and tourist institutions (Saxena, 2005; Morrison et a., 2004; Volgger \& Pechlaner, 2014). In the specific case of tourist destinations, which operate in a competitive and constantly evolving environment, relationships between actors are becoming more and more significant. Although at different levels, in fact, actors involved actively co-participate in the design and realization of the tourist destination offer such as a) tourist suppliers and $b$ ) tourists

\subsection{Relationships with Suppliers of Tourist Services}

Developing a tourist product/service (e.g. vacation spot, museum visits, etc.) requires the availability of accessory services that the individual tourist enterprise is not always able of providing internally. For this reason, tourist enterprises turn to a more or less wide group of suppliers of tourist services considered essential to the implementation of their own peculiar activity (e.g. transport enterprises, catering, etc.). The position of tourist enterprises on supply markets is strongly influenced by the criticality of the recurring resources they need (environmental, strategic and qualitative criticality of the product to be procured) and by the ability to carry out, concretely, procurement actions in line with their necessities. Indeed, the above implies a real "provisioning capability". This, in turn, is based on both the ability to contact suppliers, to guarantee the reliability of supplies, to control the technical knowledge over time, to maintain long-term relationships, and on the presence of an appropriate organizational system. In this framework, a risky element is represented by the articulation of the relationships between the purchasing enterprise and its suppliers. In this respect, it is possible to talk about "shared provisioning" to highlight the trend towards a "re-location from the "competitive triangle" (clients, competitors, enterprise) to the "cooperative rectangle" (client, competitor, enterprise, supplier)" (Kraljic, 1984). These relationships are determined by both external elements, which define the market strengths of suppliers, and by specific features of the enterprise that define its strength in terms of provisioning powers. External elements can be traced back to the more or less complex character of the supply market, expressed in terms of offer excess/deficiency, degree of concentration, intensity of renewal of materials and components, possible existence of entry barriers, localization, and size of transnational costs.

Among the specific features of the enterprise, we can include the adopted policies (e.g. collaboration relationships with suppliers, applicable also to financial aspects and to production planning, development of alternative sources, integration processes, even if partial, etc.), the size and qualitative composition of the purchase share, and the dimension of the business.

First of all, it is important to distinguish between the quality of the relationship with the supplier and the contribution of the supplier to the development of an innovative tourist product. If the nature of the tie between an enterprise and a pool of suppliers of tourist services is cooperative, it is essential to establish medium to long-term relationships with actors considered integral part of the framework of reference, sharing with them a specific business culture, opened to the external environment, and that sustains and guarantees the innovation and the durability of the enterprise/supplier relationship (Paniccia, 1995). This relationship will necessarily turn into shared goals, common participation in the planning of new tourist products/services, shared and sustained investments with a high degree of specificity.

For this reason, it is necessary to develop, within enterprises, new organizational profiles to support the management of the relationship system with suppliers of tourist services who, thanks to ICT technologies, may ensure a real time exchange of data and information (e-procurement) and rapidly understand the main expectations of the suppliers themselves.

\subsection{Relationships with Tourists}

The tourist is the customer of the tourist offer. This figure is usually considered as an indefinite part of a target to tackle with specific techniques, also of a psychological nature, and with appropriate marketing tools, with the aim to influence his purchase decisions. The need to meet the requirements of an increasingly mature tourist translates into the ability of the management to listen to the numerous requests that come from a specific 
environment and that can widely vary. The same model of environmental framework is used to highlight the importance taken by external actors who interact with the enterprise, and the consequent strategic importance given to the implementation of two-way, long-term and accountable relationships. As in other productive sectors, the tourist is not usually engaged in the planning and definition of the product to purchase. Actually, the tourist is rather seen as a passive actor of an exchange system controlled by opportunistic behaviors of tour operators and travel agencies that would study their own purchasing policies in order to develop a product coherent with the market expectations. On the contrary, the tourist/customer is no more an irrational subject, but rather a careful and competent individual when it comes to his/her purchasing decisions. First of all, it could be possible to affirm that organizational, productive and market behaviors of tourist enterprises largely depend on the features of their customers, who contribute to the definition of the rules governing the productive and commercial activities. This means leaving out the vision centered on the enterprise, particularly fit for the "Ford" model, where standardized (or differentiated) goods are offered within markets whose consumers have poor ability to choose their own expectations and needs in autonomy. That is to say, an environmental framework where the enterprise prevails in the relationships with the market, that plays a mere role of passive absorption of the offer, and where the mechanisms of collecting information, that guide the planning and creation of products, have limited and sporadic nature. As far as tourist enterprises are concerned, it is possible to confirm that a shift is under way in both the system of producing value for the end user, also due to the recent evolution of consumers' behavior, and in the type of relationship developed with the market for which the products are intended. In other words, laying much greater emphasis on the management of information coming from consumers in order to direct the planning and development of products towards the market requirements. Hence, tourist enterprises shall collect from the market all the elements on which the end user judgment will depend and that will be considered significant to evaluate the product, and act on them to develop a coherent tourist offer compliant with the expectations of the selected market segment.

\section{Conclusions and Limits}

Within the framework of the international tourist scenario, are there tourist hospitality models designed as a prototype of co-evolution between the tourist destination and its territory?

All the considerations made in so far allow us to locate the subject of co-evolution between tourist destinations and tourist enterprises within a wider perspective, starting from the type of tourist involved in relationship. Where the market segments are characterized by a substantial simplicity, the intensity of co-evolution between tourist destinations and tourist enterprises is measured upon the satisfaction of the tourist. Differently, when the market segment is more complex, the intensity of co-evolution between tourist destinations and tourist enterprises is measured through a dialectic and continuous process of trial and learning between the two subjects, as a result of the evaluation of the needs expressed by consumers. In complex competitive contexts, this goal can be achieved only through a real involvement of the consumer in the definition of the features of the tourist product/service. To define their own strategies, in order to adapt tourist offer to tourist expectations, tourist enterprises shall arrange a series of managerial mechanisms able to evaluate market needs and then finalize them in innovative products/services. Facing competitive challenges, by promoting innovation, means being able to promptly take advantage of market needs and changes and suggest new ideas. Within the Italian tourist scenario, the albergo diffuso can be considered as the Made in Italy response to the co-evolutionary process triggered between the tourist destination and the territory, identifying a new role for the small accommodating business in the local economic and social system. It refers to small tourist enterprises that were able to fit in with the territory, combining, with a foward-looking approach, traditional elements of the accommodation offer with relevant social and economic factors, such as the authenticity of territories and buildings, food and wine traditions, folklore and artisanship.

This paper represents an effort to organize the research in the tourist sector about aspects that are still not well defined. Despite the absence of case studies to support the theoretical framework, with a view to a subsequent future research, we will continue the proposed analysis by enriching it with empirical evidence, that will be useful both to foster the debate on the subject matter and for the related entrepreneurial and management implications.

\section{References}

Baggio, R., \& Cooper, C. (2010). Knowledge transfer in a tourism destination: The effects of a network structure. The Service Industries Journal, 30(10). https://doi.org/10.1080/02642060903580649

Baggio, R., Scott, N., \& Cooper, C. (2010). Improving tourism destination governance: a complexity science approach. Tourism Review, 65(4), 51-60. https://doi.org/10.1108/16605371011093863 
Beritelli, P., \& Bieger, T. (2014). From destination governance to destination leadership - defining and exploring the significance with the help of a systemic perspective. Tourism Review, 69(1), https://doi.org/10.1108/TR-07-2013-0043

Bieger, T. (1998). Reengineering destination marketing organizations - the case of Switzerland. Revue de Tourisme, 53(3), 4-17, https://doi.org/10.1108/eb058277.

Borzyszkowski, J. (2013). Destination management organizations (DMOs) and crisis management. Journal of Tourism \& Services, 4(7).

Breukel, A., \& Go, F. M. (2009). Knowledge-based network participation in destination and event marketing: A hospitality scenario analysis perspective. Tourism Management, 30(2), https://doi.org/10.1016/j.tourman.2008.05.015

Brunetti, F. (1999). Il turismo sulla via della qualità. Cedam, Padova.

Buhalis, D. (2000). Marketing the competitive destination of the future. Tourism Management, 21(1), 97-116, https://doi.org/10.1016/S0261-5177(99)00095-3

Cafferata, R. (2014). Management in adattamento. Tra Razionalità economica, evoluzione e imperfezione dei sistemi, Il Mulino, Bologna.

Casarin, F. (2007). Il marketing dei prodotti turistici. Giappichelli, Torino.

Das, T. K., \& Teng, B. S. (2002). The dynamics of alliance conditions in the alliance development process. Journal of Management Studies, 39(5), 725-756. https://doi.org/10.1111/1467-6486.00006

Della Corte, V. (2009). Imprese e sistemi turistici. Egea, Milano.

Epstein, M. J., Buhovac, A. R., \& Yuthas, K. (2010). Implementing sustainability: the role of leadership and organizational culture. Strategic Finance, 91(1), 41-47.

Flagestad, A., \& Hope, C. A. (2001). Strategic Success in Winter Sport destination: A Sustainable Value Creation Perspective. Tourism Management, 22(5), 445-461. https://doi.org/10.1016/S0261-5177(01)00010-3

Ford, R. (2012). Tourist Destination Governance: Practice, Theory, and Issues. International Journal of Contemporary Hospitality Management, 24(5), 810-812.

Franch, M. (2002) (a cura di), Destination Management. Governare il turismo tra locale e globale. Giappichelli, Torino.

Golinelli, C. M. (2002). Il territorio sistema vitale. Verso un modello di analisi, Giappichelli, Torino.

Golinelli, C. M., \& Simoni, M. (2005). La relazione tra le scelte di consumo del turista e la creazione di valore per il territorio. Sinergie, 66.

Golinelli, G. M. (2010). Viable systems approach (USA). Governing business dynamics. Cedam, Padova, p. 168 e ss.

Gulati, R., \& Gargiulo, M. (1999). Where do inter-organizational networks come from? American Journal of Sociology, 104(5), 1439-1493.

Hrebiniak, L. G., \& Joice, W. F. (1985). Organizational adaptation: Strategic Choice and Environmental Determinism. Administrative Science Quarterly.

Kraljic, P. (1984). From purchasing to supply management. The McKinsey Quarterly, 2-17.

Landorf, C. (2009). Managing for sustainable tourism: a review of six cultural World Heritage Sites. Journal of Sustainable Tourism, 17(1), 53-70. https://doi.org/10.1080/09669580802159719

Leiper, N. (1979). The framework of tourism. Annals of Tourism Review, 6(4), 390-407. https://doi.org/10.1016/0160-7383(79)90003-3.

Lewin, A. Y., \& Volberda, H. (1999). Prolegomena on Coevolution: A framework for research on strategy and new organizational forms. Organization Science, 10(5). https://doi.org/10.1287/orsc.10.5.519

Lewin, A. Y., Long, C. P., \& Carrol, T. N. (1999). The Coevolution of New Organizational Forms. Organization Science, 10(5). September-October. https://doi.org/10.1287/orsc.10.5.535

Ma, M., \& Hassink, R. (2013). An evolutionary perspective on tourism area development. Annals of Tourism Research, 41, 89-109. https://doi.org/10.1016/j.annals.2012.12.004

Martini, U. (2002). Da luoghi a destinazioni turistiche. In M. Franch (a cura di) Destination Management. 
Governare il turismo tra locale e globale. Giappichelli, Torino.

Martini, U. (2008)."Marketing strategico per il recupero della competitività delle destinazioni turistiche. In Martini U., \& J. Ejarque (Eds.), Le nuove strategie di destination marketing. Franco Angeli, Milano.

Migliaccio, M., Matarazzo, M., \& Rossi, M. (2004). Processi di cooperazione pubblico-privato e prodotti turistici evoluti. Un'opportunità per la valorizzazione delle risorse territoriali del Sannio. In F. Bencardino \& G. Marotta (Eds.), Nuovi turismi e politiche di gestione della destinazione. Franco Angeli.

Morrison, A., Lynch, P., \& Johns, N. (2004). International tourism networks. International Journal of Contemporary Hospitality Management, 16(3), 197-202. https://doi.org/10.1108/09596110410531195

Paniccia, P. (1995). Approvvigionamenti sistemici e performance operative: dal marketing d'acquisto al marketing d'approvvigionamento nell'impresa industriale, Università degli Studi di Cassino.

Paniccia, P. (2006) (a cura di), Creazione e valorizzazione della conoscenza in impresa, Aracne, Roma.

Paniccia, P., \& Leoni, L. (2017). Co-evolution in tourism: the case of Albergo Diffuso. Current Issue in Tourism, 20(17), 1-28, https://doi.org/10.1080/13683500.2017.1367763

Paniccia, P., Silvestrelli, P., Montella, M., Rozera, C., \& Valeri, M. (2014). Innovare nell'ottica della sostenibilità. L'esempio dell' "albergo diffuso": un progetto di valorizzazione per il territorio. In M. Franch \& M. Martini (a cura di), Management per la sostenibilità dello sviluppo turistico e la competitività delle destinazioni, Il Mulino, Bologna.

Parkhe, A., Wasserman, S., \& Ralston, D.A. (2006). New frontiers in network theory development. Academy of Management Review, 31(3), 560- 568, https://doi.org/10.5465/amr.2006.21318917

Pechlaner, H., \& Weiermair, K. (2000) (a cura di). Destination management. Fondamenti di marketing e gestione delle destinazioni turistiche, Touring Editore, Milano.

Pechlaner, H., Abfalter, D., \& Lange, S. (2009) (eds.), Culture and creativity as location factors - looking beyond metropolitan areas, Innsbruck Univ. Press.

Pechlaner, H., Kozak, M., \& Volgger, M. (2014). Destination leadership: a new paradigm for tourist destinations? Tourism Review, 69(1), 1-9, https://doi.org/10.1108/TR-09-2013-0053

Pechlaner, H., Paniccia, P., Valeri, M., \& Raich, F. (2011) (a cura di). Destination governance, Giappichelli, Torino, 2011.

Pechlaner, H., Volgger, M., \& Herntrei, M. (2012). Destination management organizations as interface between destination governance and corporate governance. Anatolia: An International Journal of Tourism and Hospitality Research, 23(2), 151-168, https://doi.org/10.1080/13032917.2011.652137

Pencarelli, T. (2001). Marketing e performance nell'industria turistica, Quattro Venti editore, Urbino.

Ruhanen L., Scott, N., Ritchie, B., \& Tkaczynski, A. (2010). Governance: a review and synthesis of the literature. Tourism Review, 65(4), 4-16, https://doi.org/10.1108/16605371011093836

Sainaghi, R. (2006). From Contents to Processes: Versus a Dynamic Destination Management Model (DDMM). Tourism Management, 27(5), 1053-1063. https://doi.org/10.1016/j.tourman.2005.09.010

Saxena, G. (2005). Relationships, networks and the learning regions. Tourism Management, 26(2), 277-289.

Schianetz, K., Kavanagh, L., \& Lockington, D. (2007). The Learning Tourism Destination: The potential of a learning organization approach for improving the sustainability of tourism destinations. Tourism Management, 28(6), 1485-1496, https://doi.org/10.1016/j.tourman.2007.01.012

Sciarelli, S. (2007). Il management dei sistemi turistici locali. Strategie e strumenti per la governance, Giappichelli, Torino.

Soda, G., Usai, A., \& Zaheer, A. (2004). Network memory: The influence of past and current networks on performance. Academy of Management Journal, 47, 893-906. https://doi.org/10.5465/20159629

Tamma, M. (2000). Aspetti strategici del destination management. In H. Pechlaner \& K. Weiermair (a cura di) Destination management. Fondamenti di marketing e gestione delle destinazioni turistiche, Touring University Press, Milano.

Tamma, M. (2002). Destination Management: gestire prodotti e sistemi locali di offerta. In M. Franch (a cura di), Destination Management. Governare il turismo fra locale e globale, Giappichelli, Torino.

Trunfio, M. (2008). Governance Turistica e Sistemi Turistici Locali. Modelli teorici ed evidenze empiriche in 
Italia, Giappichelli, Torino.

Valeri, M. (2013). Evoluzioni dell'impresa turistica. Agriturismi e alberghi diffusi, Aracne, Roma.

Valeri, M. (2015). Sustainability development and competitiveness of Rome as a tourist destination. Tourism and Hospitality Management, 21(2), 203-218, https://doi.org/10.20867/thm.21.2.7

Valeri, M. (2016). Prospettive co-evolutive nel settore turistico: il caso dell'albergo diffuso. Esperienze d'Impresa, 2, 19-37.

Valeri, M., \& Baiocco, S. (2012). The integration of a Swedish minority in the hotel business culture: the case study Riva del Sole. Tourism Review, 67(1), 51-60. https://doi.org/10.1108/16605371211216378

Valeri, M., \& Paoloni, P. (2016). Capitale relazionale e sviluppo sostenibile nelle micro e piccole imprese di servizi, in Paoloni, P. (a cura di), Studi di genere: il mondo femminile in un percorso interdisciplinare, Edicusano editore, Roma, 2016.

Valeri, M., \& Paoloni, P. (2017). Competitiveness and sustainability in tourism industry: the albergo diffuso case study. International Journal of Business and Management, 12(12), 107-118. https://doi.org/10.5539/ijbm.v12n12p107

Valeri, M., Pechlaner, H., \& Gon, M. (2016) (a cura di), Innovazione, sostenibilità e competitività. Teoria ed evidenze empiriche, Giappichelli editore, Torino.

Volberda, H. W., \& Lewin, A. Y. (2003). Co-evolutionary Dynamics Within and Between Firms: From Evolution to Co-evolution. Journal of Management Studies, 40(8), 2111-2136. https://doi.org/10.1046/j.1467-6486.2003.00414.x

Volgger, M., \& Pechlaner, H. (2014). Requirements for destination management organizations in destination governance: Understanding DMO success. Tourism Management, 41(2), 64-75. https://doi.org/10.1016/j.tourman.2013.09.001

Weick, K. E. (1969). The social psychology of organizing, Random House, New York, 1969 (trad. it. Organizzare. La psicologia sociale dei processi organizzativi, Isedi, Milano, 1993).

Yin, X., Wu, J., \& Tsai, W. (2012). When Unconnected Others Connect: Does Degree of Brokerage Persist After the Formation of a Multipartner Alliance. Organization Science, 23(6), 1682-1699. https://doi.org/10.1287/orsc.1110.0711

\section{Copyrights}

Copyright for this article is retained by the author(s), with first publication rights granted to the journal.

This is an open-access article distributed under the terms and conditions of the Creative Commons Attribution license (http://creativecommons.org/licenses/by/4.0/). 